\title{
CRITERIA AND INDICATORS of Sustainable Forest Management in Canada
}

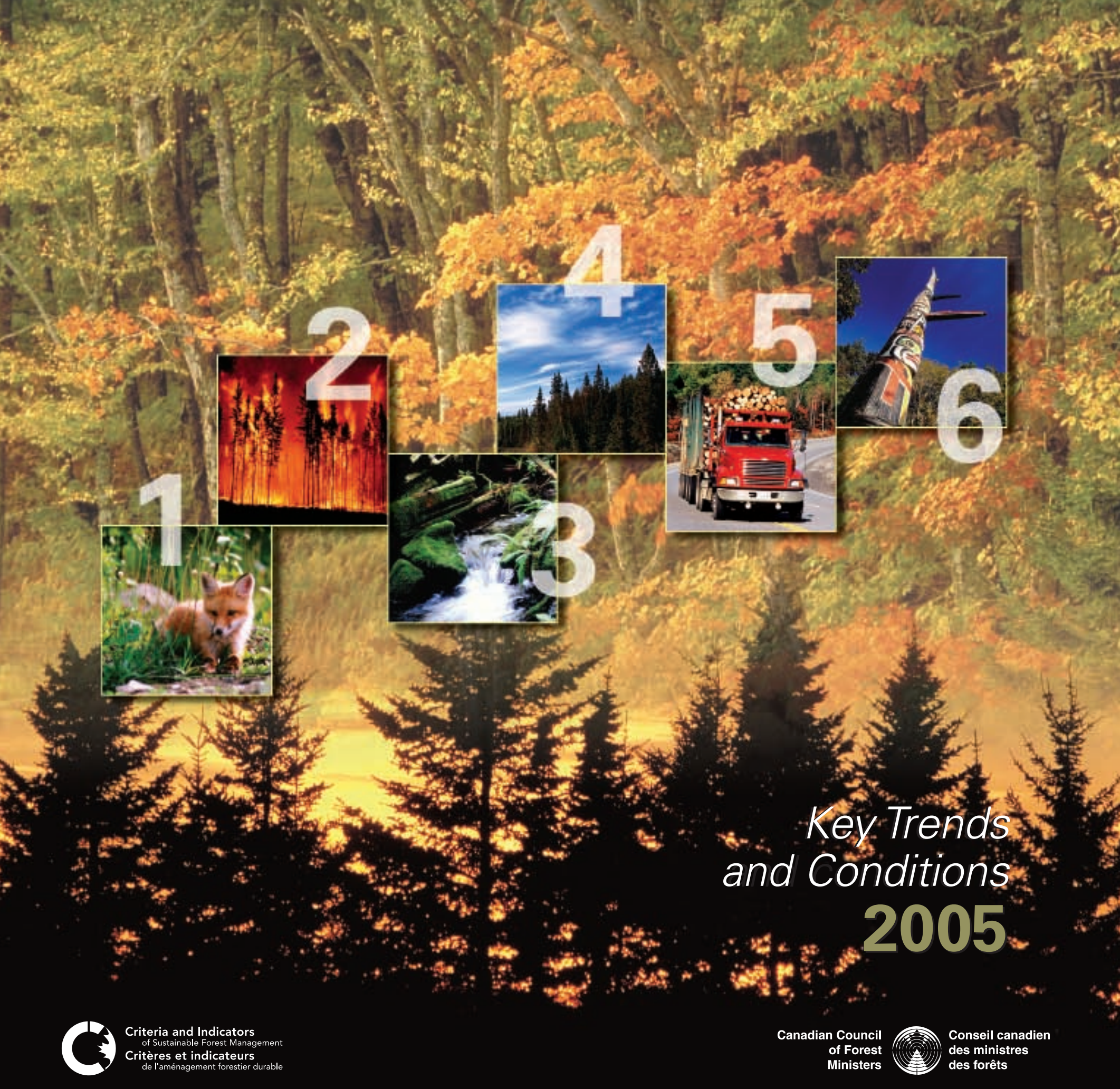




\section{BiOlOGiCAL DiverSity}

Maintaining biological diversity, or biodiversity, allows organisms and ecosystems to respond and adapt to environmental change.
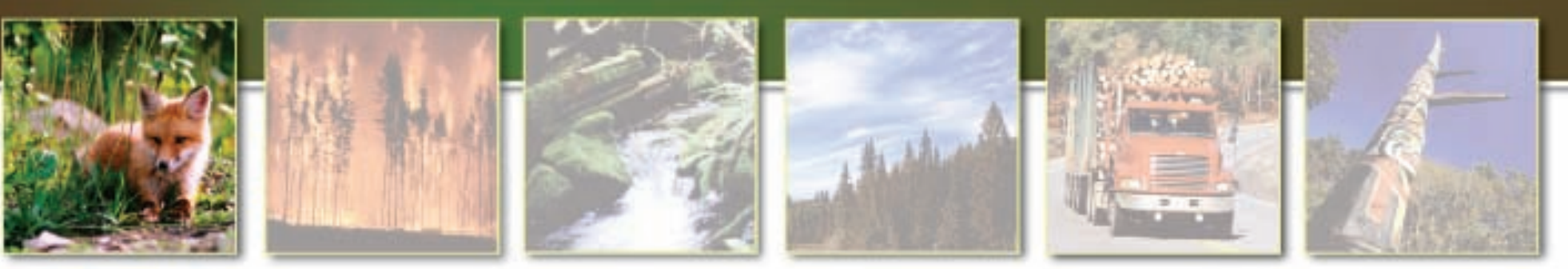

\section{CANADA'S FORESTS COVER 4O2. 1 MILLION HECTARES (HA), ABOUT 10 PERCENT OF THE WORLD'S FORESTS.}

Most of Canada's forests are comprised of coniferous species, although deciduous species are also important. The dominant age class is $41-80$ years old, although forests in some areas, like the temperate rain forests of the West Coast, can be much older. Canada also has 134.6 million ha of wetlands - about 25 percent of the world's total.

\section{MORE THAN 31 MILLION HA OF FORESTS AND 9.6 MILLION HA OF WETLANDS ARE PROTECTED.}

Canada's National Forest Strategy calls for a national network of protected areas. Almost 8 percent of Canada's forests are protected. These areas contain many examples of Canada's forest biodiversity.

\section{FOREST SPECIES ARE DESIGNATED "AT RISK."}

There was a 27 percent increase in the number of forest-associated species at risk between 1999 and 2004. This is consistent with a 31 percent increase in the total number of species assessed, highlighting that data availability is one of the main factors affecting the number and change in status of designated species at risk.

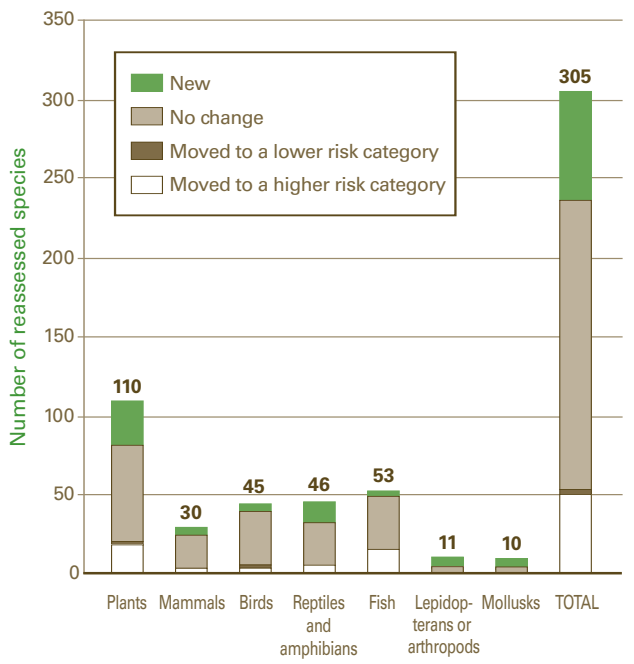

Change in status of forest-associated species-at-risk reassessed between 1999 and 2004. Included are extirpated, endangered, threatened and special concern species designated by the Committee on the Status of Endangered Wildlife in Canada.

\section{MANY FOREST ANIMALS HAVE STABLE OR INCREASING POPULATIONS, BUT DECLINES IN SOME SPECIES ARE A CONCERN.}

Across Canada, many forest mammal and bird species that are being monitored are assessed as stable or increasing. However, declining populations of such species as the woodland caribou and the American marten are a concern, because these species are often associated with mature and old forests - locations where forestry activities frequently occur. For these and other species, governments have developed, or are developing, practices to conserve the species and minimize forest-management impacts.

\section{GOVERNMENTS ARE RESPONDING TO THE THREAT POSED BY NON-NATIVE SPECIES TO CANADA'S FOREST BIODIVERSITY.}

Although Canada has increased detection efforts at ports of entry, the number of non-native (alien) invasive species has increased. Federal, Provincial and Territorial Governments are working together to implement An Invasive Alien Species Strategy for Canada to address this threat.

Estimated number of alien species in Canada (preliminary)

\begin{tabular}{ll}
\hline Vascular plants & At least 27\% of all vascular plants \\
\hline Birds & 24 \\
\hline Mammals & 26 \\
\hline Reptiles & 2 \\
\hline Amphibians & 4 \\
\hline Fish & 55 \\
\hline Terrestrial arthropods & $>1500$
\end{tabular}

CANADA'S FOREST-MANAGEMENT PRACTICES ARE DESIGNED TO RETAIN GENETIC DIVERSITY.

Most harvested areas regenerate naturally, but for the roughly 15 percent that do not, programs and policies are in place to help ensure that planted trees have adequate genetic variation. Across Canada, 58 tree species require genetic conservation measures. Many of these species are from the Carolinian forest of southern Ontario, where populations have been severely reduced, largely due to urbanization and agriculture. Several temperate-zone conifers, such as white and red pine, have also suffered sharp population declines, due to harmful harvesting practices in the early nineteenth century and the introduction of diseases and pests. Modern harvesting practices have improved substantially, and specific conservation initiatives have been established for several tree species. 


\section{ECOSystem CONDITION AND PROduCtivity}

Canada's forest ecosystems must be able to cope with and recover from natural and human disturbances to maintain their ecological functions and processes. Some disturbances, such as wildfires, play a key role in forest renewal.
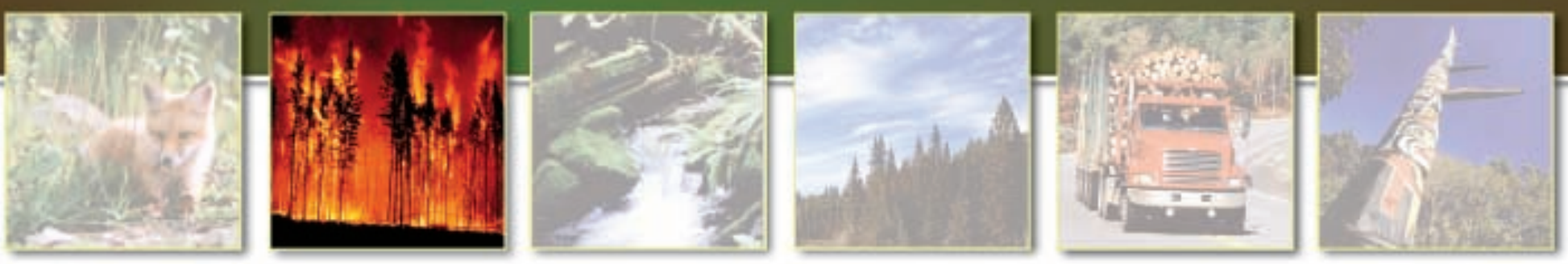

NATURAL DISTURBANCES PLAY AN IMPORTANT ROLE IN THE FUNCTIONING OF CANADA'S FOREST ECOSYSTEMS.

Natural disturbances, like wildfire and insect defoliation, affect millions of hectares but are part of the natural functioning of forest ecosystems and help maintain biodiversity. Insect outbreaks tend to be cyclical, with peak populations occurring in particular years and certain regions of the country. For example, British Columbia is currently experiencing an infestation of mountain pine beetles. While management strategies are being implemented to curtail the infestation, mild winters and abundant mature lodgepole pine have enabled beetle numbers to reach unprecedented levels.

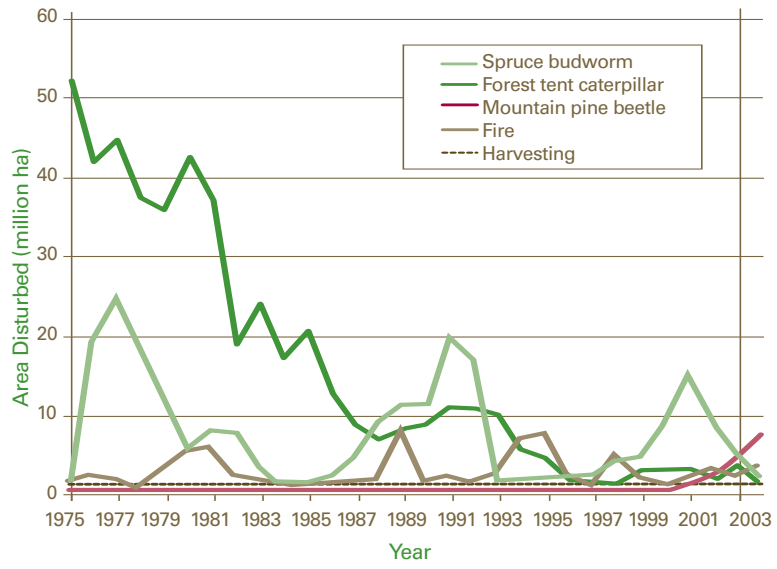

Area disturbed by fire, harvesting and selected insects in Canada (1975-2004)

\section{LESS THAN I PERCENT OF CANADA'S 29 BILLION CUBIC METRES $\left(M^{3}\right)$ OF MERCHANTABLE WOOD IS HARVESTED ANNUALLY.}

Canada's boreal and Pacific maritime forests contain over 80 percent of Canada's merchantable wood. In 2003, 177.4 million $\mathrm{m}^{3}$, or 0.6 percent of the total volume, were harvested. However, in any given year, as much as 239 million $\mathrm{m}^{3}$ could be harvested on public and private land. In terms of area, about 900000 ha of forest are harvested annually. In most cases, companies harvesting Crown forests must ensure that the forest grows back promptly to maintain the productivity of the ecosystem. The area considered not adequately reforested is gradually shrinking; by 2001, it had fallen to just under 2.1 million ha from 2.4 million ha in 1993.

\section{LESS THAN 0.02 PERCENT OF CANADA'S FOREST AREA IS CONVERTED TO OTHER LAND USES EACH YEAR.}

Research is underway to improve available information, but it is estimated that every year less than 0.02 percent of Canada's forests (up to 80000 ha) is permanently converted to other uses, such as cities, agricultural land, roads and range. Some areas are also converted back to forest from other land uses. About 6000 ha were converted to forest in 2001, down from 10000 ha in 1990.

\section{ACID RAIN AND OZONE CONTINUE TO AFFECT FORESTS IN SOUTHEASTERN CANADA AND SOUTHERN BRITISH COLUMBIA, ALTHOUGH POLLUTANT EMISSIONS HAVE STABILIZED.}

Ozone and acid rain slowly degrade forests over many years. The cumulative and combined effects of ozone and acid rain on forests are still a concern, especially in southeastern Canada. Research is ongoing to quantify the effects of these combined pollutants.

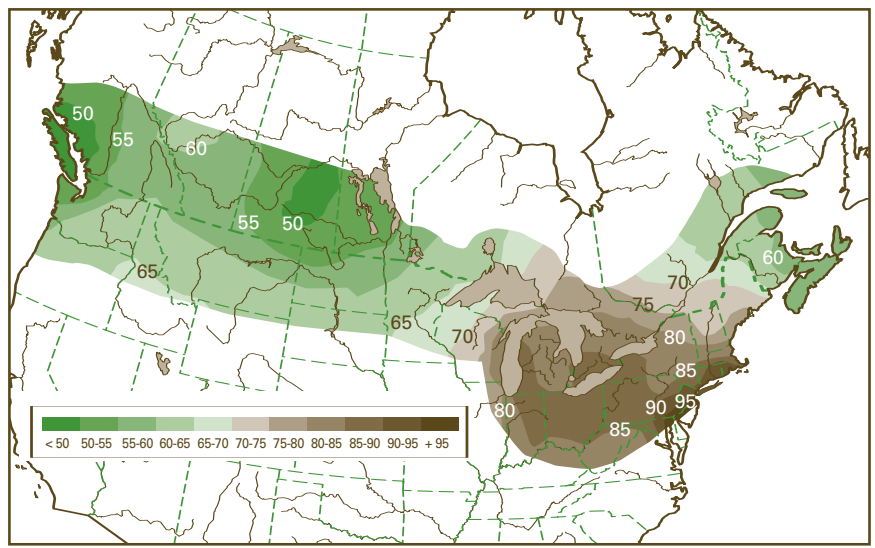

Ozone concentrations (parts per billion), 2000-2002. 


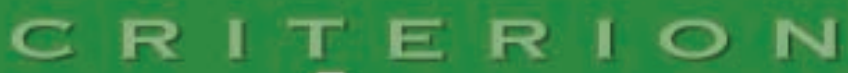

\section{Role in GLOBal ECOLOGical CyCles}

Forests play a key role in the global ecological cycles. They depend on and contribute to selfregulating processes responsible for recycling carbon, water, nitrogen, and other life-sustaining elements. Forest management can impact the role of forests in the carbon cycle.
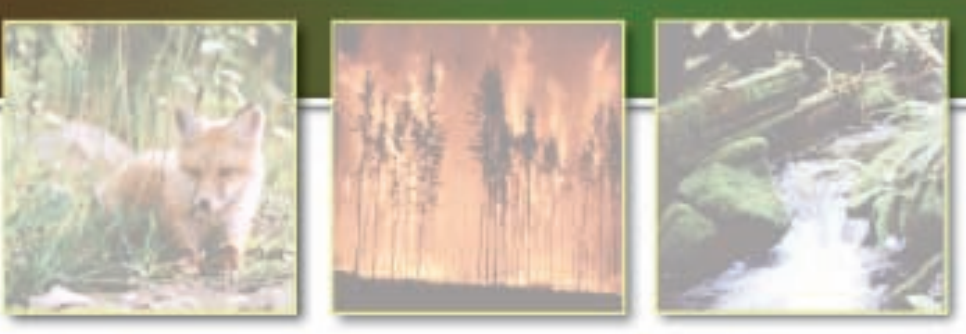

\section{EARLY ESTIMATES INDICATE THAT CANADA'S FORESTS STORE MORE THAN 84 BILLION TONNES OF CARBON.}

Forests play a key role in the global carbon budget by absorbing, storing and releasing atmospheric carbon dioxide, a key greenhouse gas (GHG) linked to global climate change. Canada has a responsibility to understand how its forests contribute to global carbon cycles. Based on earlier versions of the Canadian carbon budget model, estimates published in 2000 indicated that Canada's forests contained more than 84 billion tonnes of carbon. Researchers are improving the country's carbon budget model to provide more accurate and up-to-date estimates.

\section{IN THE PAST, CANADA'S FORESTS HAVE RELEASED AN AVERAGE OF 44.6 MILLION TONNES OF CARBON PER YEAR INTO THE ATMOSPHERE.}

According to estimates published in 2000, Canada's forests, on average, released more carbon into the atmosphere each year through decay, fire and other processes than they took up through growth. Year-toyear variation is closely linked with natural disturbances like wildfires. Improved models, available in the near future, will provide more up-to-date estimates. In addition, more than 4 million tonnes of carbon are stored in forest products each year.

\section{THE FOREST INDUSTRY HAS KEPT GHG EMISSIONS AT 1980 LEVELS DESPITE A 23 PERCENT INCREASE IN ENERGY USE AND 30 PERCENT INCREASE IN PULP AND PAPER PRODUCTION.}

The forest industry, Canada's largest industrial energy user, has kept emissions at 1980 levels by improving energy efficiency and using cleaner fuels, such as natural gas and bioenergy. Bioenergy accounts for more than 55 percent of the total energy used by the forest industry, up from 47 percent in 1980.
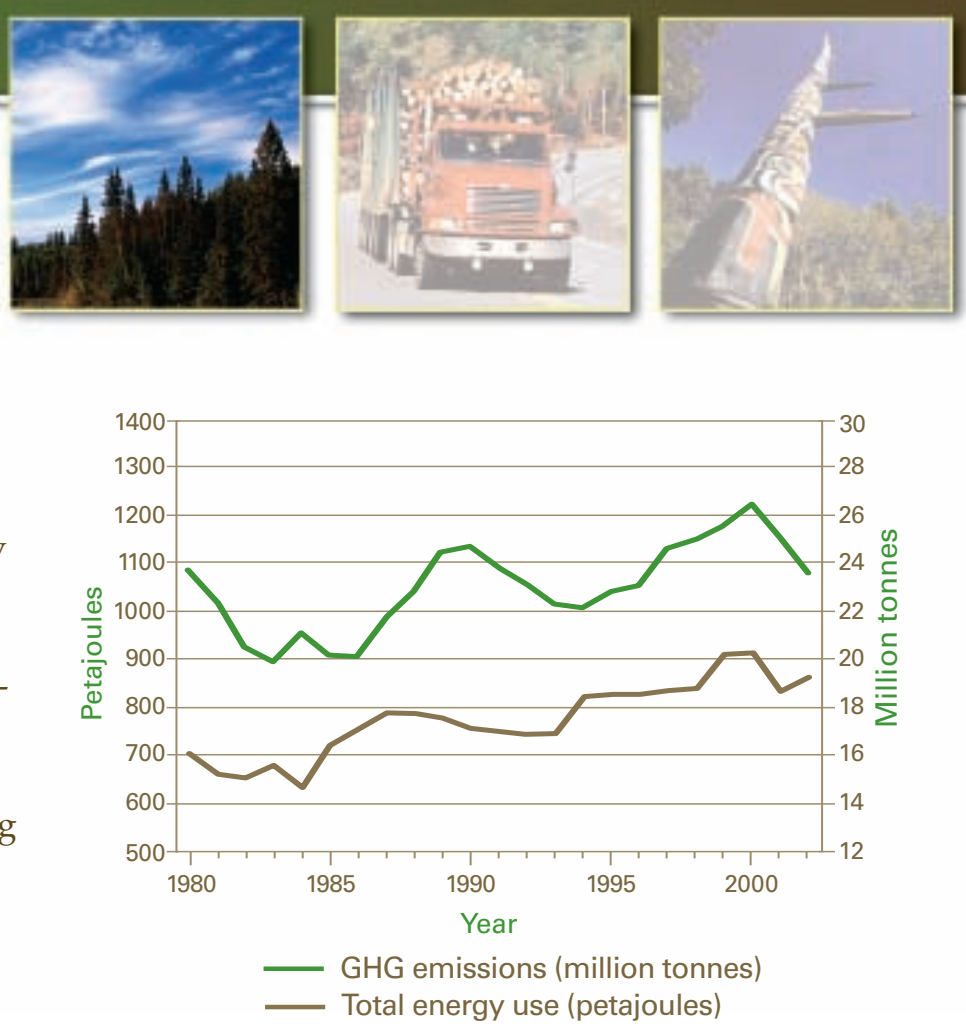

Forest sector GHG emissions and total energy use

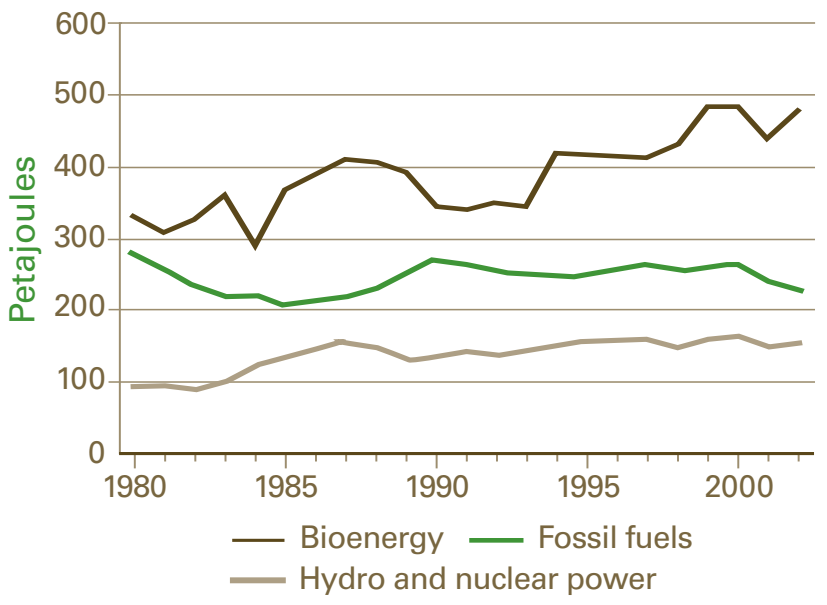

Forest sector energy sources 


\section{ECONOMIC AND SOCIAL BENEFITS}

Sustainable forest management ensures forests provide a broad range of goods and services over the long term, offering significant economic and social benefits.
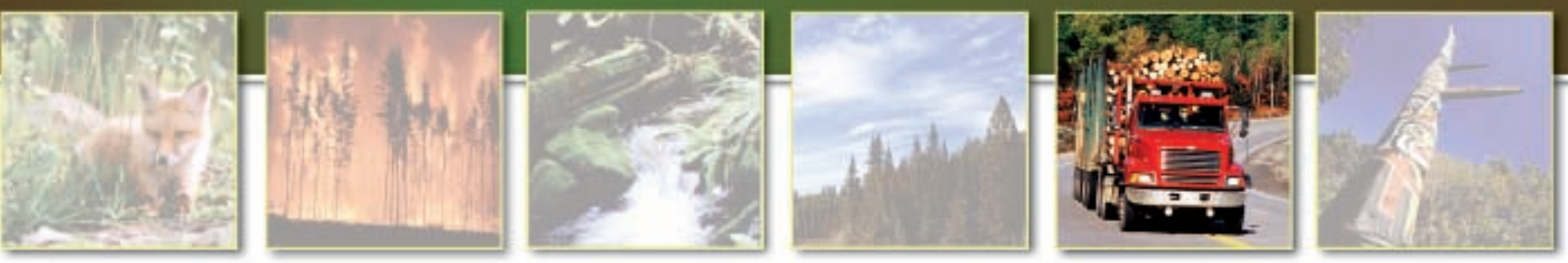

\section{SALES OF TIMBER PRODUCTS HAVE GROWN TO \$77 BILLION, BUT THE FOREST INDUSTRY'S RELATIVE CONTRIBUTION TO CANADA'S GDP HAS FALLEN TO AROUND 3 PERCENT.}

The forest industry's contribution to Canada's gross domestic product (GDP) fell by about half a percentage point per decade from 1961 to 1982 . The forest industry did expand during that period - volumes and shipments of timber increased in real terms - just not as quickly as the rest of the economy. Thus, the forest industry's relative contribution to the GDP, $\$ 37.5$ billion in 2005, is currently less important than it used to be. The industry's contribution to the GDP has been more stable recently, due largely to growth in the wood industries sub-sector. However, the contribution of the forestry, logging and pulp and paper sub-sectors continues to decline.

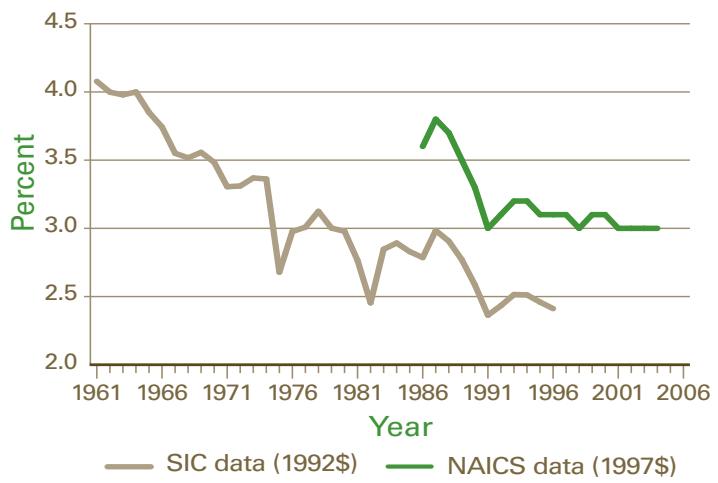

Contribution of the forest industry to Canada's GDP (\%) $(S I C=$ Standard Industrial Classification; NAICS = North American Industry Classification System)

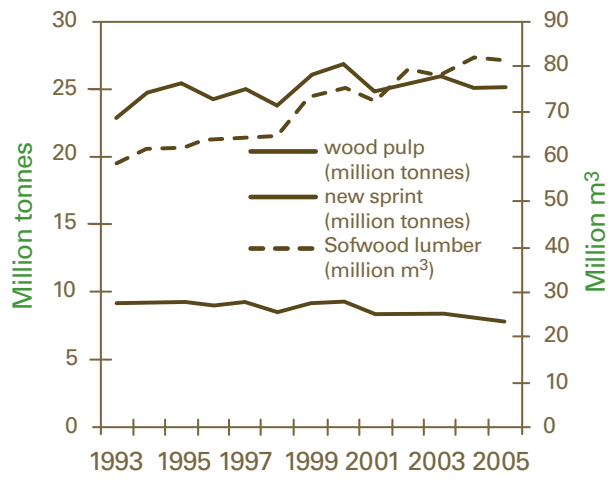

Production of timber products in Canada

\section{SECONDARY MANUFACTURING OF TIMBER PRODUCTS HAS RAPIDLY EXPANDED, INCREASING ECONOMIC BENEFITS WITHOUT INCREASING THE HARVEST.}

Secondary manufacturing (e.g., making cabinets from wood panels) increases the contribution of the forest industry to the GDP, revenue and employment without increasing the harvest. Ontario, where about 40 percent of the Canadian population lives and about half of the housing starts occur, has the most secondary manufacturing industries.

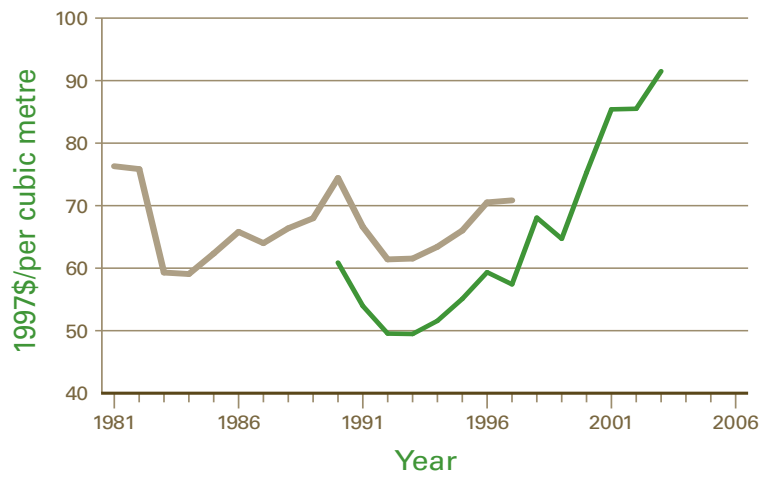

— SIC data N NAICS data

Canadian shipments of secondary manufacturing products per volume harvested

\section{THE VALUE OF CANADA'S NON-TIMBER FOREST} PRODUCTS SECTOR IS SIGNIFICANT AND GROWING.

Estimated current output of forest-based foods (FBF) in the Canadian economy

\begin{tabular}{lccc}
\hline $\begin{array}{l}\text { FBF } \\
\text { commodity }\end{array}$ & $\begin{array}{c}\text { Output in } \\
\text { tonnes or } \\
\text { litres (000) }\end{array}$ & $\begin{array}{c}\text { Current } \\
\text { economic } \\
\text { value } \\
\text { million \$) }\end{array}$ & $\begin{array}{c}\text { Additional } \\
\text { economic } \\
\text { potential } \\
\text { million \$) }\end{array}$ \\
\hline Honey & 37072 & 161 & 1000 \\
\hline Tree saps & 34761 & 164 & 31 \\
\hline Berries & 149373 & 279 & 164 \\
\hline Mushrooms & 1 & 43 & 26 \\
\hline Understorey plants & 2 & 75 & 115 \\
\hline Wild rice & 1013 & 3 & 753 \\
\hline Total & & 725 & 2089 \\
\hline
\end{tabular}

NEW TENURE ARRANGEMENTS ARE MAKING MORE FOREST RESOURCES AVAILABLE TO SMALL ENTERPRISES AND COMMUNITIES.

Canada has a mix of Crown tenure arrangements that confer the right to harvest certain forest resources, usu- 

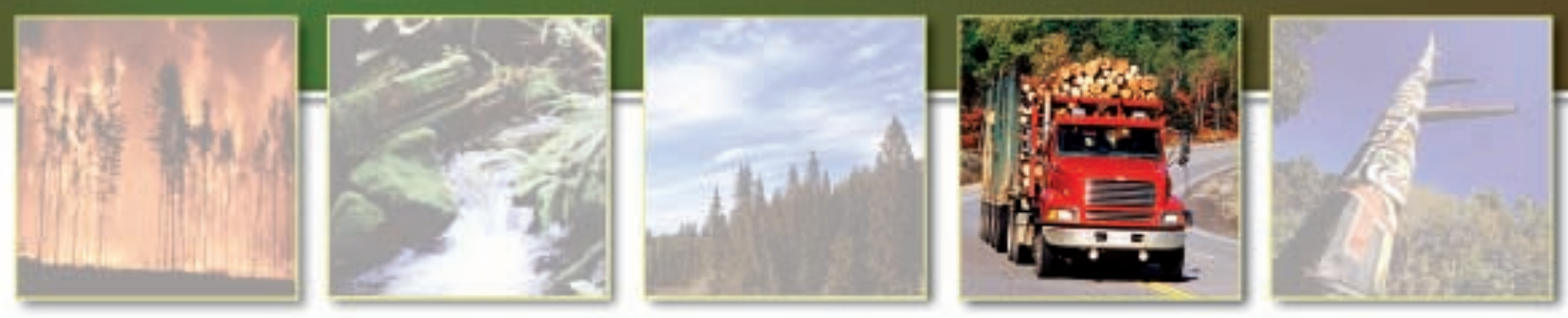

ally timber. In return, tenure holders pay fees to the Crown and must respect rules to protect the resource. New types of tenure have been introduced since 1990 often to make Crown forest resources available to small- and medium-sized enterprises, communities and Aboriginal peoples. For example, the Yukon, Nova Scotia, Saskatchewan and the Northwest Territories have conferred 11,12, 16 and 30 percent, respectively, of their forest volumes to Aboriginal peoples.

\section{LABOUR, BUSINESSES AND GOVERNMENTS SHARE BILLIONS OF DOLLARS IN BENEFITS FROM THE TIMBER PRODUCTS INDUSTRY.}

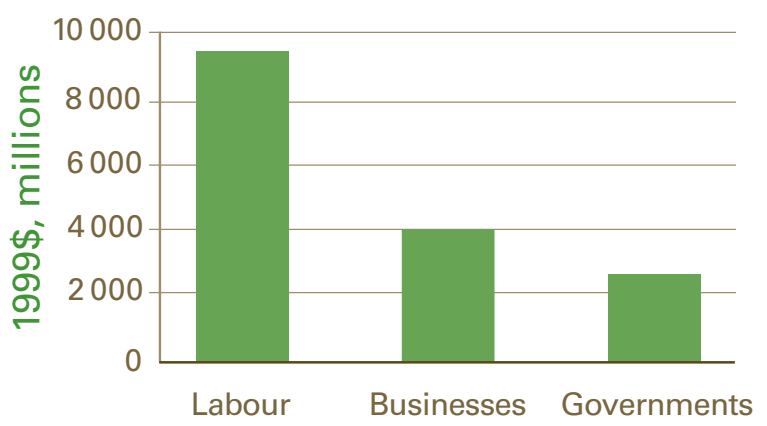

Average annual financial benefits distributed to labour, businesses and governments in the form of wages, profits, taxes and so on (1990-2002)

THE VOLUME OF TIMBER HARVESTED ON PROVINCIAL CROWN LANDS HAS INCREASED 22 PERCENT SINCE 1990 BUT REMAINS BELOW THE ALLOWABLE ANNUAL CUT (AAC).

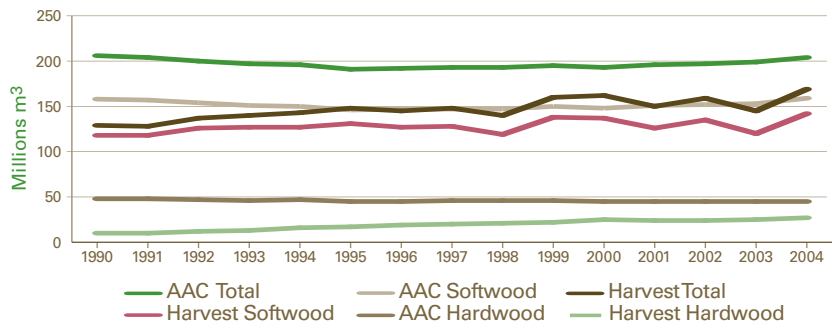

LOW RATES OF RETURN ON CAPITAL EMPLOYED (ROCE) IN CANADA'S FOREST INDUSTRY MAKE IT DIFFICULT TO ATTRACT INVESTMENT.

Canadian forest companies have faced challenges attracting the private investment necessary to increase productivity when their international competitors often have a higher ROCE. The forest sector, particularly pulp and paper, is an industry with high capital costs. In the last couple of years, the ongoing lack of capital investment, coupled with low pulp and paper prices, has led to poor returns in the pulp and paper sub-sector. Lumber and panel producers have fared better, benefiting from stronger prices and higher capital investment, with consequent better returns.

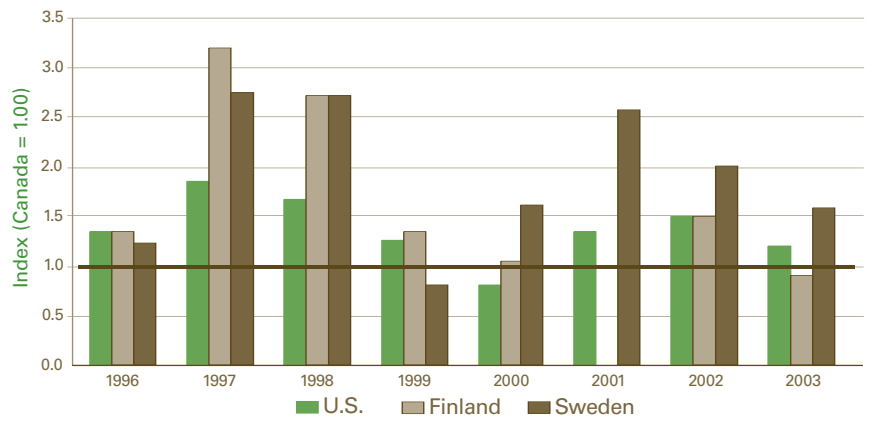

International comparisons (Canada $=1.00$ ) of the return on capital investment performance

\section{THE FOREST INDUSTRY PROVIDES HUNDREDS OF THOUSANDS OF WELL-PAYING JOBS, ALTHOUGH EMPLOYMENT HAS DECLINED RECENTLY.}

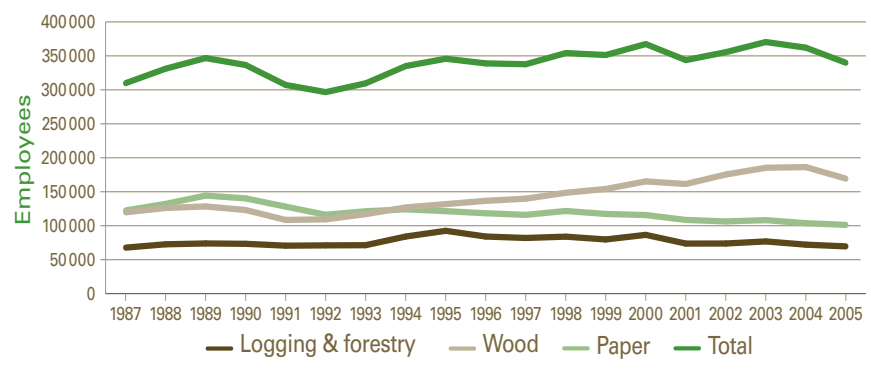

The industry has generated over 330000 direct jobs since 1995, reaching a record of over 370000 jobs in 2003. Wages are generally higher than, or equal to, wages in manufacturing as a whole. Between 2003 and 2005, however, the industry lost over 30000 jobs. Many of these jobs were in the pulp and paper subsector, which has experienced a downturn resulting in several mill closures. Wood-products manufacturing, where jobs have been increasing since 1991, also suffered a setback. 


\section{SOCIETY'S RESPONSIBILITY}

Forest practices should reflect social values since operations often take place on publicly owned lands, and many rural communities depend on the forest for their economic,
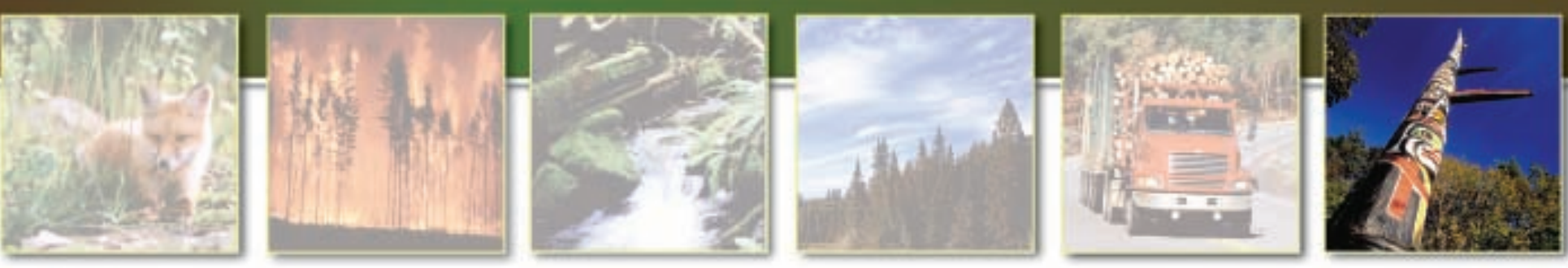

\begin{abstract}
ABORIGINAL CONSULTATION AND INVOLVEMENT IN FOREST-MANAGEMENT PLANNING HAS INCREASED, BUT INFORMATION ABOUT TRADITIONAL KNOWLEDGE AND ITS APPLICATION TO FOREST MANAGEMENT IS LACKING.
\end{abstract}

Aboriginal peoples in Canada have strong ties to the forest, and over the past several years, improvements have been made in the way governments and industry consult with and involve Aboriginal peoples in forest management. In addition, more forest land is coming under Aboriginal control through land claims, treaty land entitlements and additions to reserves, which may lead to greater economic opportunities. In recent years, the value of Aboriginal traditional ecological knowledge (ATEK) in contemporary forest management has been recognized. Provinces and territories have undertaken efforts to gather information on ATEK, but more work is needed to transfer this knowledge to non-traditional users.

\section{FOREST-DEPENDENT COMMUNITIES ARE GENERALLY LESS WELL OFF THAN OTHER RURAL COMMUNITIES.}

About 350 Canadian communities depend on the forest industry, and about 80 percent of Aboriginal communities are located in forest areas. On average, while forest-based communities have higher economic diversity - which helps communities weather shocks in their economy - they are not as well off as other rural communities in terms of education, employment and income. As a result, they may be less able to respond to rapid changes in their social, economic and environmental systems. This is something governments and others are working to address through the National Forest Strategy and other initiatives.

\section{MOST PUBLIC PARTICIPANTS FEEL THAT THEIR INVOLVEMENT IN FOREST-MANAGEMENT PLANNING IS WORTHWHILE.}

Local citizen advisory committees are a common way to foster public participation in forest management in Canada. Recent survey results show that 74 percent of public participants are somewhat or completely satisfied with the committee process. More than two thirds of participants feel that the process is fair. And slightly more than half feel that decisions accommodate the full spectrum of public interests and that participants are able to influence committee decisions.

\section{COMPLIANCE WITH FOREST LAWS AND REGULATIONS, A PREREQUISITE FOR SUSTAINABLE FOREST MANAGEMENT, IS GENERALLY HIGH IN CANADA.}

Canada's sustainable forest-management laws, regulations and other standards are continuously updated to reflect the best available scientific knowledge. Information available from six provinces shows high rates of compliance - from 86.0 to 99.5 percent. Where inspections found non-compliance, operators had to correct the results of their actions and change their practices to comply or face closure.

\section{PUBLIC ACCESS TO FOREST INFORMATION IMPROVES DISCUSSION AND DECISION MAKING.}

Forest inventories are using a wide range of technologies to collect information for a broad range of topics. In general, data on Crown lands are accessible, and information on private lands is becoming increasingly available to the public.

\section{DIRECT SCIENCE AND TECHNOLOGY (S\&T) FUNDING AND PURCHASES OF TECHNOLOGY AND SERVICES ARE IMPROVING FOREST MANAGEMENT.}

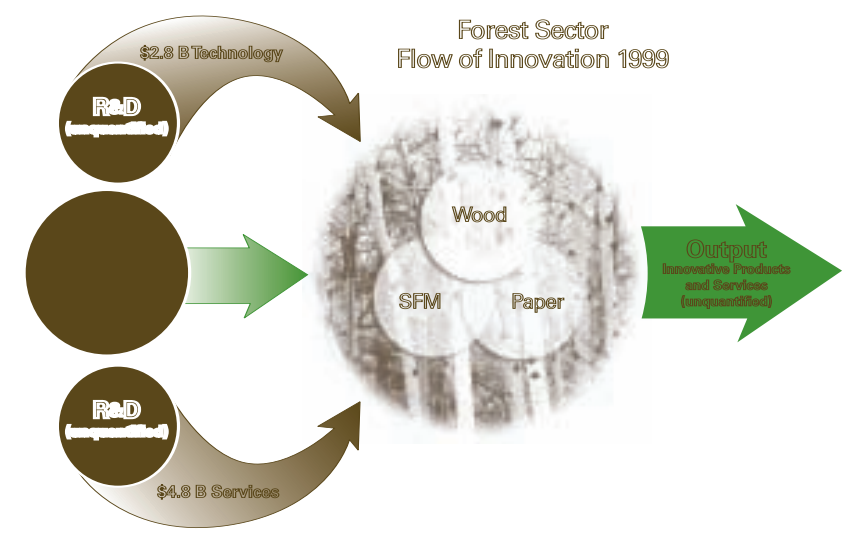




\section{CONTINUOUS IMPROVEMENT IN Sustatnabie Foriest Managemient}
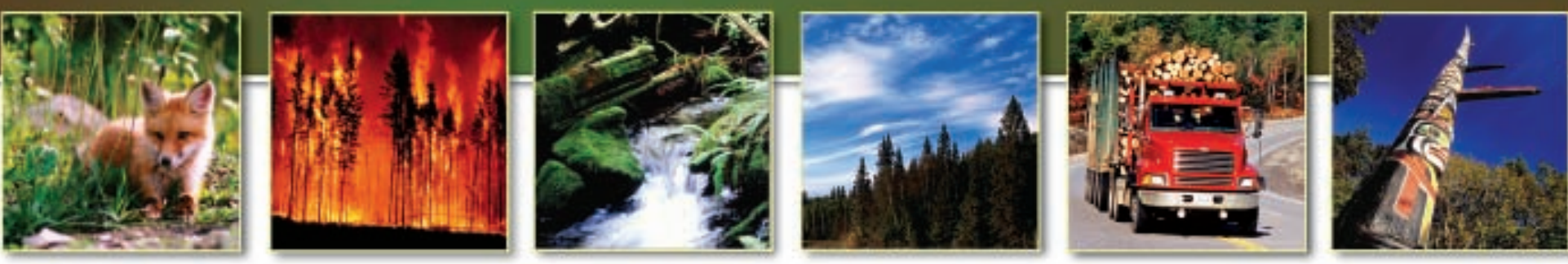

\section{OVERALL, CANADA CONTINUES TO MAKE SOLID PROGRESS TOWARD SUSTAINABLE FOREST MANAGEMENT, BUT IT MUST ADDRESS KEY ISSUES IF IT IS TO REMAIN A WORLD LEADER.}

Canada's forests are among the largest in the world and are at the heart of Canada's growth and prosperity. They provide economic and social benefits for all Canadians and support a diversity of species over vast landscapes with dynamic, ever-changing ecosystems. Modern forest management in Canada is a model of how progress toward sustainability can be achieved. Increased consultation has led to forest management that incorporates a broad array of values and recognizes the dynamism of ecological and social systems, as well as the benefits of adaptive management and collaboration.

To remain a leader in sustainable forestry, Canada must, among other things, reduce or prevent the impacts of pollution and alien invasive species on forests, continue to increase Aboriginal participation in forest management and improve the resilience and well-being of forest communities.

Also, the forest industry must become more competitive in the international marketplace by continuing to apply leading-edge innovation to forest management and manufacturing. It must develop value-added products and new markets for products. Efforts must also be made by governments, industry and others to improve information on forest-based services and sustainable harvest levels of non-timber forest products.

Forest policy-makers and managers in Canada will continue to face difficult choices because of divergent opinions about priorities for managing forest resources. Criteria and Indicators of Sustainable Forest Management in Canada helps governments do the following:

- evaluate the effectiveness of existing regulations;

- orient future policies;

- identify and prioritize information and research;

- guide forest practices; and

- clarify expectations of sustainable forest management in Canada.

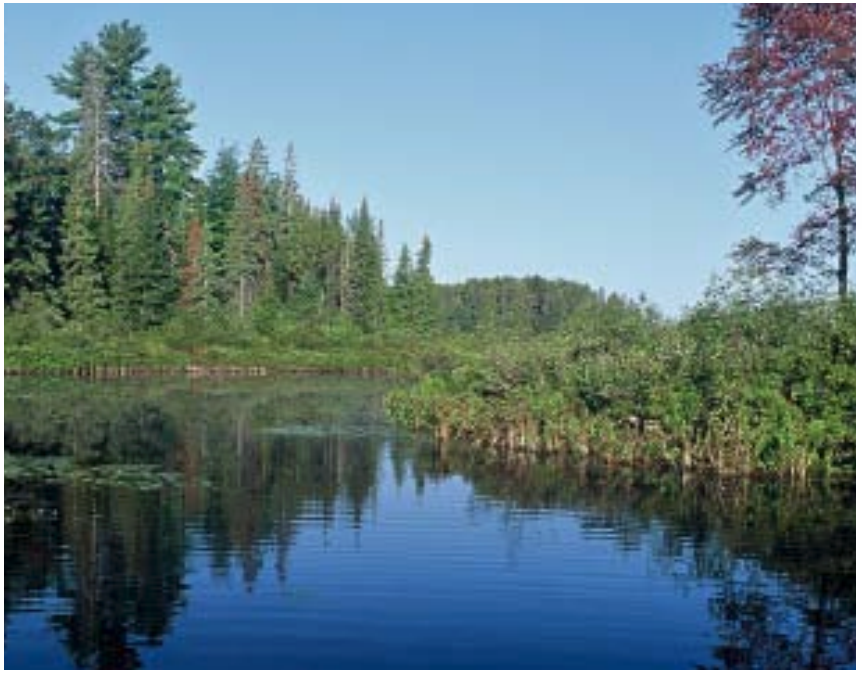

The information provided through Criteria and Indicators also helps Canadians better understand the options available for managing the forest and participate more effectively in decision making.

The Criteria and Indicators report is the result of extensive collaboration and cooperation among federal, provincial and territorial governments. By working together, governments have increased their capacity to report. To improve future reporting, the Canadian Council of Forest Ministers (CCFM) is considering a new National Forest Inventory that will improve the trend estimates for many of the CCFM indicators. The CCFM is also expanding its National Forestry Database to collect and store new information on forests and forest management. And

it is developing a National Forest Information System to improve access to information via the Internet. These initiatives will add to the solid forestry data already in place and enhance the nation's capacity to assess and report on the state of its forests. 


\section{FRAMEWORK OF CRITERIA AND INDICATORS OF SUSTAINABILE FOREST MANA GEMIENT}
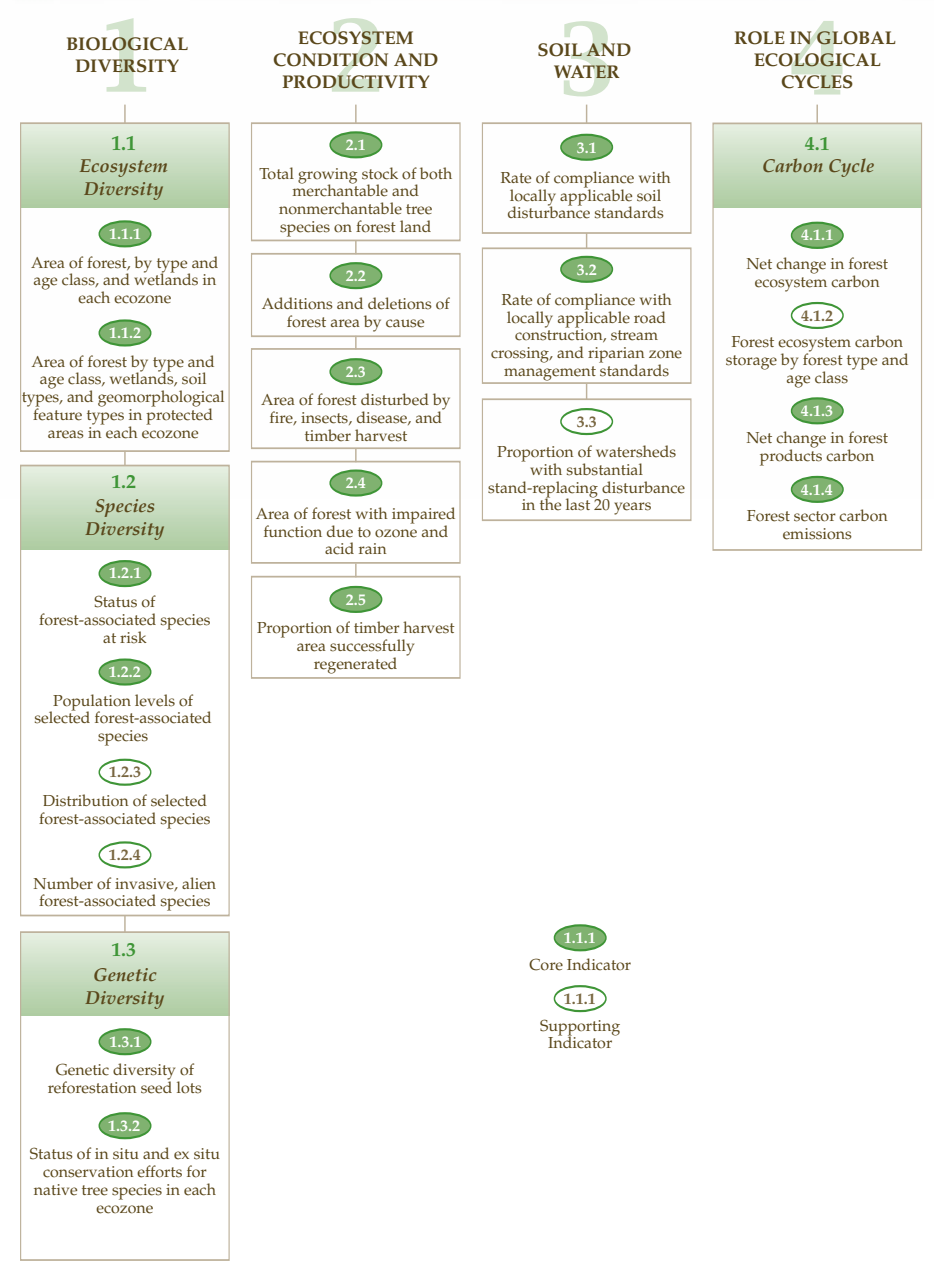

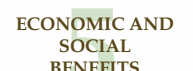

BENEFITS

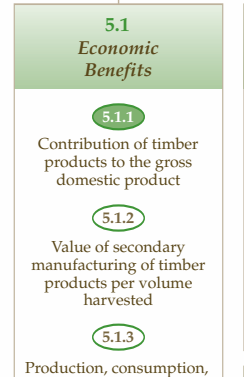

Production, consumption, import products
timber

5.1.4

Contribution of nontimber forest products and forest-based services to the
gross domestic product

5.1 .5

Value of unmarketed and forest-bast services
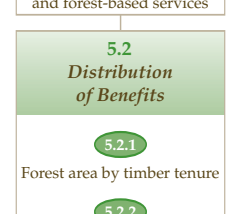

5.22

Distribution of financial products industry

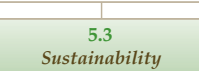

Sustainability of Benefits

5.3 .1

Annual harvest of timbe relative to the level of havest 5.2 .2 Annual harvest of relative to the level of arvest deemed to be ustainable

5.3 .3 Return on capital employed 5.3 .4 Productivity index 5.3 .5

Direct, indirect, and induced employmen

5.3 .6

Average income in major employment categories
SOCIETY'S RESPONSIBILITY

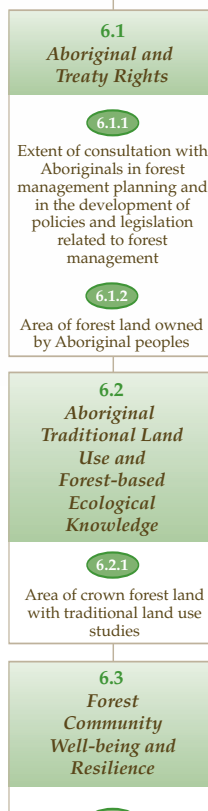

6.3 .1

Economic diversity index of 6.3 .2

Education attainment levels 6.3 .3

Employment rate in forest-based communities

6.3.4

Incidence of low income in forest-basd om nities

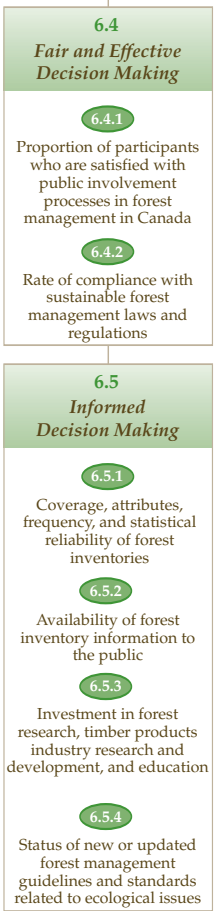




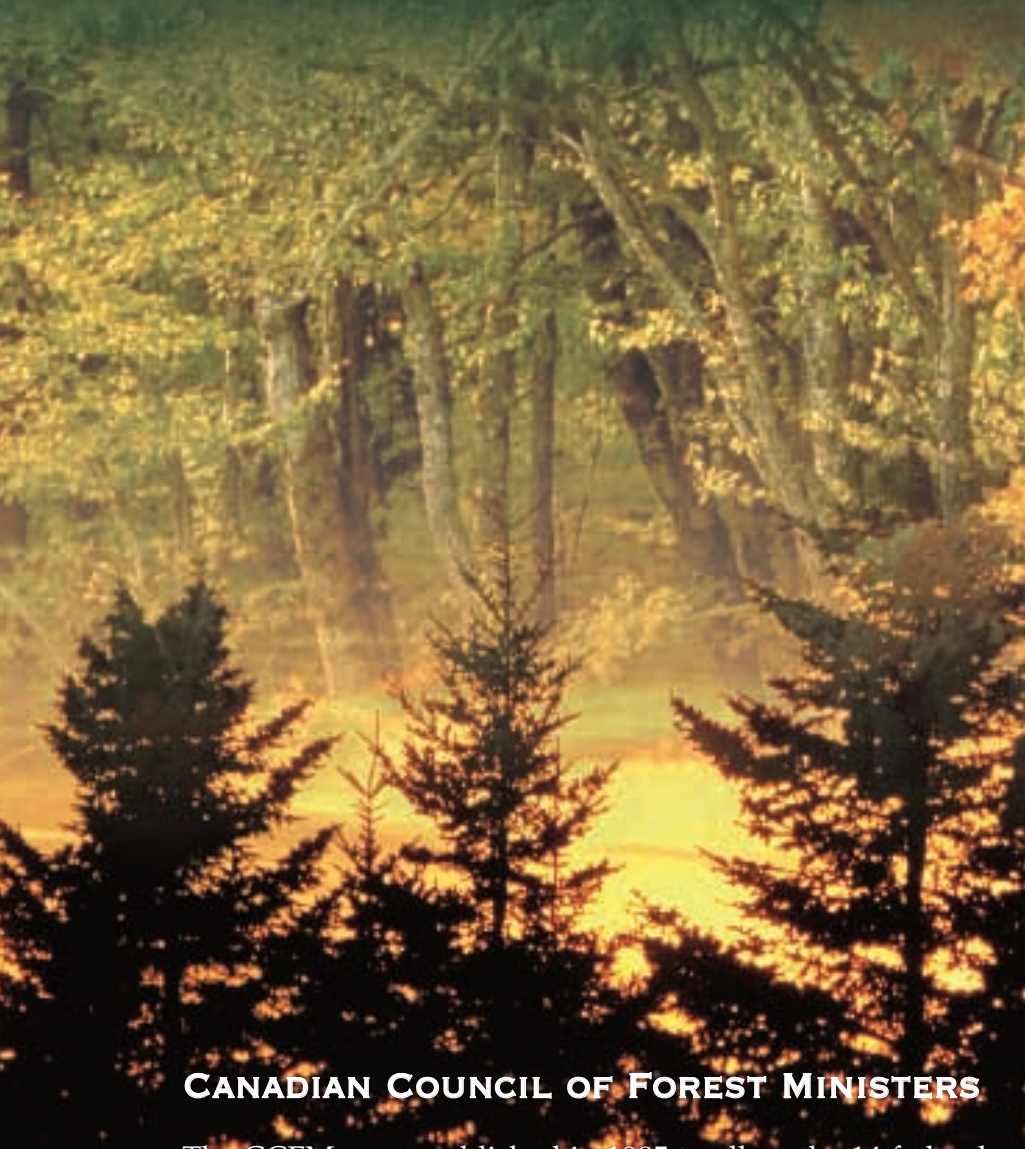

The CCFM was established in 1985 , to allow the 14 federal, provincial and territorial ministers with responsibility for forests to cooperate more closelý in major areas of common interest. The Council provides leadership on national and ${ }^{2}$ international issues and sets direction for the stewardship and sustainable management of Canada's forests.

More information on the Council can be found on-line at www.ccfm.org.

\section{TO READ MORE}

You can learn more about the work of the CCFM and its Criteria and Indicators (C\&I) initiative. The report Criteria and Indicators of Sustainable Forest Management in Canada: National Status 2005 is available on the Internet at www.ccfm.org/ci/index_e.php. This report provides an indepth analysis of the six criteria and 46 indicators showing Canada's progress toward sustainable forest management. Copies may also be obtained free of charge from

Natural Resources Canada

Canadian Forest Service

580 Booth Street

Ottawa ON K1A 0E4

E-mail: cfs-scf@nrcan.gc.ca

(C) Her Majesty the Queen in Right of Canada, 2007

(8) 1
INTERNATIONAL REPORTING ON TEMPERATE AND BOREAL FORESTS ins:-

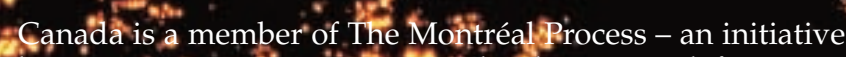
by 12 countriesuto "use cettiter fand andicators to define, " 2 ismeasure and report on progress toward the conservation $\quad \cdots$ and sustainable management of temperate and boreal forests. Together, these 12 countries represent 60 percent of the world's forests and account for nearly half of the world trade in forest products. In 1995, the member countries endorsed a framework of 7 criteria and 67 indicators, and in 2004, they launched a process to improve the indicators.

Canada uses the CCFM C\&I framework to meet its Montréal Process reporting obligations. The two frameworks are compatible, with considerable alignment in the values important to both processes. Membership in The Montréal Process is part of Canada's overall commitment to promote sustainable forest management. Canada is also proud to have housed the Liaison Office for The Montréal Process since 1995, which acts as a secretariat for the process. For more information on The Montréal Process, refer to its Web site at www.mpci.org.

(c) Canadian Council of Forest Ministers, 2006

ISBN 978-0-662-44500-5

Cat. No. F04-8/2005-1E (Print)

ISBN 978-0-662-45755-8

Cat. No. F04-8/2005-1E-PDF (Electronic)

Cette publication est aussi disponible en français sous le titre

Critères et indicateurs de l'aménagement forestier

durable au Canada : bilan national 2005 - Sommaire 